\title{
Performance, Heritability and Genetic Advance for Oil Yield and some Economical Characters in Oil Palm (Elaeis guineensis Jacquin) of Cameroon
}

\author{
Penampilan, Heritabilitas dan Kemajuan seleksi pada karakter \\ Produksi Minyak dan beberapa Sifat Ekonomi Kelapa Sawit dari Kamerun
}

\author{
Mondjeli Constantin $^{1,2}$, Sobir $^{3^{*}}$, Muhamad Syukur ${ }^{3}$, and Willy Bayuardi Suwarno ${ }^{3}$ \\ ${ }^{1}$ Graduate student of Plant Breeding and Biotechnology Major, Graduate School of Bogor Agricultural University \\ ${ }^{2}$ Specialized Centre for Oil Palm Research of Cameroon (CEREPAH-IRAD), 243 Douala, Cameroon \\ ${ }^{3}$ Department of Agronomy and Horticulture, Faculty of Agriculture \\ Bogor Agricultural University, Jl. Meranti Kampus IPB Darmaga, Bogor 16680, Indonesia
}

Received 28 November 2016/Accepted 28 February 2017

\begin{abstract}
Knowledge of the magnitude of genetic variability, heritability and genetic advance in the selection of desirable characters could assist the plant breeders in ascertaining criteria to be used in the breeding programmes. Twenty three introgressed oil palm progenies were evaluated at the Specialized Centre for Oil Palm Research of Cameroon, from 2004 to 2014 to estimate performance, genetic variability, heritability and genetic advance of oil yield and some economic traits in terms to select new oil palm parent materials with the traits of interest. The results revealed high variability among oil palm population for all the characters. Moderate estimates of the phenotypic and genotypic coefficient of variations associated with high heritability and moderate genetic advance as percent of mean were obtained for characters of fresh fruit bunch, bunch number, oil yield, kernel to bunch, kernel to fruit, kernel yield and height increment. The results suggest the effectiveness of selection method for these traits and their improvement through their phenotypic performance. LM11087T x LM2749D and LM12960T X LM7409D were obtained as superior oil palm crossing parents with the potential production of 6.26 ton $^{-1} \mathrm{ar}^{-1}$ of crude palm oil; they can be exploited in seed production and further breeding program.
\end{abstract}

Keywords: genetic advance, heritability, introgressed progenies, oil yield, Phenotypic

\section{ABSTRAK}

Ketersediaan informasi parameter pemuliaan sangat penting untuk mendukung program pemuliaan kelapa sawit yang efektif. Penelitian ini bertujuan untuk mengetahui besaran keragaman genetik, heritabilitas dan tingkat kemajuan seleksi pada karakter-karakater yang menjadi target pemuliaan pada kelapa sawit dari Kamerun. Evaluasi dilakukan terhadap 23 progeni introgresi kelapa sawit di Specialized Centre for Oil Palm Research of Cameroon, mulai tahun 2004 hingga 2014, untuk parameter keragaman genetik, heritabilitas dan kemajuan seleksi pada karakter produksi minyak dan beberapa sifat lain yang memiliki nilai ekonomi. Hasil penelitian menunjukkan terdapat keragaman genetik yang tinggi diantara populasi yang dievaluasi untuk semua karakter yang diamati. Karakter bobot tandan segar, jumlah tandan, produksi minyak, nisbah kernel terhadap tandan, nisbah kernel terhadap buah, nisbah kernel terhadap produksi dan pertambahan tinggi tanaman memiliki koefesien keragaman genetik dan fenotifik yang moderat, dengan heritabilitas yang tinggi serta kemajuan seleksi yang moderat. Persilangan LM11087T x LM2749D dan LM12960T x LM7409D merupakan kombinasi tetua yang menghasilkan hasil persilangan superior dengan tingkat produksi minyak sawit rata-rata of 6.26 ton ha ${ }^{-1}$ per tahun sehingga dapat dilanjutkan ke produksi benih komersial atau digunakan dalam program pemuliaan di masa mendatang.

Kata kunci: fenotipik, heritabilitas, progeni introgresi, kemajuan seleksi

\section{INTRODUCTION}

Oil palm (Elaeis guineensis Jacq.) is a perennial tropical forest plant originated from the wild regions of West and

\footnotetext{
* Corresponding author. e-mail: rsobir@yahoo.com
}

Central Africa. The palms are currently produced in African, Southeast Asian and Central and South American countries. Oil palm fruits are exploited from mesocarp (crude palm oil: CPO) and endocarp (palm kernel oil: PKO) of fruits. It is the most productive and economically attractive vegetable crop for smallholders, companies and government of oil palm producer countries. Palm oil is used in diverse range of 
commercial products, ranging from margarine and cooking oils to animal feeds, cosmetics, plastics, surfactants, soaps, detergents, herbicides as well as biofuels and a broad range of agricultural chemicals (Colon-Ramos et al., 2007; Ladeia et al., 2008; Van Rooyen et al., 2008). Thus palm oil demand is increasing tremendously (Jekayinfa and Bamgboye, 2008; Sumathi et al., 2008).

Oil palm is a cross-pollinated, perennial monocotyledon plant with $2 \mathrm{n}=32$ chromosomes (Singh et al., 2013). Therefore, significant variability in oil palm population are reported (Okwuagwu et al., 2008; Noh et al., 2014). Heritability is one of important parameter in breeding program which indicates how strongly a particular character can pass on from parent to progeny. In oil palm genetic improvement, the heritability estimates and their contribution towards oil yield are important parameters. Noh et al. (2014) has reported the heritability of bunch quality component characters of oil palm.

The genetic advance estimate, associated to heritability, will give rise to selection effectiveness for useful promising lines in crop improvement. They are main key parameters for plant breeder in selection (Okwuagwu et al., 2008; Okoye et al., 2009; Jalal and Ahmad, 2012). The expected genetic advance is the gain produced by selection, which contributed to change the population mean. In quantitative genetic study the estimation of genetic progress from selection has been greatly contributed in plant breeding (Okwuagwu et al., 2008; Sungkono et al., 2009). In oil palm, the bunch component like fresh fruit bunch yield (FFB), which is a product of the number of bunches (BN) and average bunch weight $(\mathrm{ABW})$, represents a major determinant of oil palm productivity (Okwuagwu et al., 2008). In this view, the selection effectiveness for heritable FFB components would rapidly advance the oil palm breeding program. Murphy (2009) has estimated the field CPO potential production (912 tons) of some oil palm Tenera varieties.

Cameroon is one of the most African provider countries of oil palm wild population and commercial oil palm elite material in the world. Unfortunately, Cameroon currently produces an estimated amount of 230,000 tons CPO per year from the plantation area of about 190,000 ha (Hoyle and Levang, 2012) and it is the World's 13th largest producer (USDA 2016). In Cameroon, palm oil accounts for about $90 \%$ of edible oil needs; Ngando et al. (2011) has reported the national palm oil consumption estimate of $80 \%$ of population. Under favourable agro-ecological conditions, oil palm plantation can produce up to 7.2 tons CPO ha- ${ }^{1}$ and 1.5 ton PKO ha-1 (Caliman, 2011). In fact, compare to estates in Southeast Asian countries, average yield is extremely low in Cameroon, i.e., 2.3 tons CPO ha${ }^{1}$ year- ${ }^{1}$ in the agro-industry and 0.8 ton CPO ha- year $^{1}$ in smallholdings (Hoyle and Levang, 2012).

Currently, new lands of about 500,000 ha were allocated by the government for the implementation of new oil palm estates to improve palm oil production. With an annual national production of about 2,500,000 of improved Tenera oil palm seed of the second cycle of selection, the current oil palm research center of Cameroon: CEREPAH and PAMOL which are in charged to provide oil palm seed to palm oil producer cannot satisfy the seed demand for such new lands. New oil palm yielding line parents are needed to improve the current low production of oil palm seeds. It is in that light that the $3^{\text {rd }}$ cycle of selection of oil palm of CEREPAH breeding program was carried out. The promising oil palm parent crosses from the new progeny trials are expected to increase the number of the current oil palm parents used in the seed production department of CEREPAH. This paper highlights the performance and the estimation of genetic variability, heritability and genetic advance of some traits in the new oil palm breeding population of the Specialized Centre for Oil Palm Research of Cameroon, in terms to provide information for seed production of high palm oil yielding lines and for advancing the current population into the next generation.

\section{MATERIALS AND METHODS}

The oil palm experiment was carried out in 2004 at the government research center of Cameroon, namely Specialized Centre for Oil Palm Research (CEREPAH), $\left(3^{\circ} 46^{\prime}-4^{\circ} 01^{\prime} \mathrm{N}\right.$ and $9^{\circ} 44^{\prime}-10^{\circ} 04^{\prime} \mathrm{E}$, at less than $200 \mathrm{~m}$ above the sea level). The research region was located in the Guinean equatorial climate with four seasons. During the research activities, annual climate data were $2730.49 \mathrm{~mm}$ of mean rainfall, temperature $23.95{ }^{\circ} \mathrm{C}-30.81{ }^{\circ} \mathrm{C}$ (average $27.36{ }^{\circ} \mathrm{C}$ ) and 1334 hours of mean sunshine. The sandy clay soils were found in this region.

The trial was focused on progeny test and contained a total of 23 oil palm introgressed progeny population crosses from Deli dura x La Mé tenera (DxT). The Dabou dura materials family originating from the National Centre for Agronomic Research (CNRA) in Ivory Coast Breeding Programme was used as female parents. The male parents were the La Mé tenera family, the descendants of the crosses between Widikum from CEREPAH-Cameroon and La Mé. All the crosses of the progeny test are pesented in Table 1.

For the mean comparisons evidence, one of the current elite tenera commercial hybrid oil palm materials of CEREPAH was used as control oil palm material in this experiment. The randomized complete block design was applied with three replications in the experimental field. The oil palm trees with one year old were laid down in equilateral triangular planting system at $9 \mathrm{~m}$ apart with 12 palm plants per progeny in 3 replications. Thus a total of 864 oil palm trees ( 6 ha) were used for observation. The recommended agronomic practices were also used to raise a good crop stand. Oil palm foliar survey was carried out and fertilizers were applied at six year old after planting at the rate of $0.487 \mathrm{~kg}$ per palm of urea, $0.951 \mathrm{~kg}$ per palm of potassium chloride and $0.166 \mathrm{~kg}$ per palm of magnesium sulfate. The trait data were recorded from 2004 to 2014 on yield components, i.e., fresh fruit bunch weight (FFB), bunch number $(\mathrm{BN})$, kernel to fruit ratio $(\mathrm{K} / \mathrm{F})$, kernel to bunch ratio $(\mathrm{K} / \mathrm{B})$, oil yield $(\mathrm{OY})$ and kernel yield $(\mathrm{KY})$, following the method of Mandal and Kochu (2008) (Table 2 ). The palm height increment (HT), was calculated by using the formula reported by Noh et al. (2014): Height 
Constantin et al. / J. Agron. Indonesia 45(2):212-219

Table 1. Progeny tested oil palm D x T population planted in 2004-2014 at CEREPAH Cameroon

\begin{tabular}{|c|c|c|c|c|c|}
\hline Progenies & Parents & $\begin{array}{c}\text { Origin of } \\
\text { tenera/pisifera }\end{array}$ & $\begin{array}{l}\text { Origin of } \\
\text { dura }\end{array}$ & $\begin{array}{c}\text { Origin of grand } \\
\text { parent Tenera/Pisifera }\end{array}$ & $\begin{array}{l}\text { Origin of grand } \\
\text { parent Dura }\end{array}$ \\
\hline LM 21661 & LM2T x DA115D & BRT10 & Dabou & & \\
\hline LM 22478 & LM5100D x LM11096T & DA2356 & LM9838 & DA115 D x LM269D & LM2T x WI 10T \\
\hline LM 21761 & LM11087T x LM2749D & LM9175 & DA787 & LM5T x WI 15T & DA10D x DA3D \\
\hline LM 22099 & LM11087T x LM7409D & LM9175 & LM7899 & LM5T x WI 15T & LM3257D AF \\
\hline LM 22001 & LM11088T x LM2531D & LM9175 & DA507 & LM5T x WI 15T & DA115D AF \\
\hline LM 22527 & LM11088T x LM2781D & LM9175 & DA787 & LM5T x WI 15T & DA10D x DA3D \\
\hline LM 22534 & LM11088T x LM7811D & LM9175 & LM7899 & LM5T x WI 15T & LM3257D AF \\
\hline LM 21884 & LM11089T x LM2749D & LM9175 & DA787 & LM5T x WI 15T & DA10D x DA3D \\
\hline LM 21864 & LM12963T x LM5100D & LM9175 & DA2356 & LM5T x WI 15T & DA115 D x LM269D \\
\hline LM 22130 & LM11091T x LM2749D & LM9287 & DA787 & LM5T x WI 1T & DA10D x DA3D \\
\hline LM 21709 & LM11091T x LM5100D & LM9287 & DA2356 & LM5T x WI 1T & DA115 D x LM269D \\
\hline LM 21706 & LM11097T x LM2531D & LM9927 & DA507 & LM5T x WI 10T & DA115D AF \\
\hline LM 21787 & LM11097T x LM5100D & LM9927 & DA2356 & LM5T x WI 10T & DA115 D x LM269D \\
\hline LM 21839 & LM11097T x LM7422D & LM9927 & LM7899 & LM5T x WI 10T & LM3257D AF \\
\hline LM 21925 & LM7422D x LM11091T & LM7899 & LM9287 & LM3257D x LM3257D & LM5T x WI 1T \\
\hline LM 21728 & LM12960T x LM5100D & LM9287 & DA2356 & LM5T x WI 1T & DA115D x LM269D \\
\hline LM 21790 & LM12960T x LM7409D & LM9287 & LM7899 & LM5T x WI 1T & LM3257D AF \\
\hline LM 21881 & LM12961T x LM2509D & LM9287 & DA507 & LM5T x WI 1T & DA115D AF \\
\hline LM 22575 & LM12961T x LM2749D & LM9287 & DA787 & LM5T x WI 1T & DA10D x DA3D \\
\hline LM 21852 & LM12961T x LM5155D & LM9287 & LM2911 & LM5T x WI 1T & LM269D x DA115D \\
\hline LM 21886 & LM12965T x LM2509D & LM9927 & DA507 & LM5T x WI 10T & DA115D AF \\
\hline LM 21867 & LM12965T x LM2749D & LM9927 & DA787 & LM5T x WI 10T & DA10D x DA3D \\
\hline LM 21874 & LM12967T x LM2781D & LM9927 & DA787 & LM5T x WI 10T & DA10D x DA3D \\
\hline LM 21836 & LM12967T x LM2509D & LM9927 & DA507 & LM5T x WI 10T & DA115D AF \\
\hline
\end{tabular}

increment/year $=($ height at year $\mathrm{t}) /(\mathrm{t}-2)$, where, $\mathrm{t}$ : is the age of the palm.

Analysis of variance of the recorded data was carried out using computer statistic $\mathrm{R}$ program software (3.3.1.Version). The Duncan Multiple Range Test was used to separate mean of each studied characters. The response to selection estimate, the genotypic coefficient of variation (GCV) and phenotypic coefficient of variation (PCV) were adopted in this study as suggested by Bello et al. (2012). The broad sense heritability $\left(\mathrm{h}^{2}{ }_{\mathrm{bs}}\right)$ estimate was the ratio of genotypic variance $\left(\sigma_{g}^{2}\right)$ and phenotypic variance $\left(\sigma_{p}^{2}\right)$. However the expected genetic advance (GA) as per cent of means with $10 \%$ of selection intensity, were estimated using the formula suggested by Bello et al. (2012).

\section{RESULTS AND DISCUSSION}

Analysis of Variance

The information from the analysis of variance showed significant different among the tested oil palm genotypes for fresh fruit bunch yield (FFB), number of bunches (BN), oil yield (OY), kernel to bunch (K/B), Kernel to fruit $(\mathrm{K} / \mathrm{F})$, kernel yield (KY) and height increment (HT) (Table 3). The result was indicating the presence of important variability among this breeding population. Thus it was inferring the feasibility of optimum selection process to release superior candidate with high oil palm commercial characters from these 23 progenies of the third cycle of selection in Cameroon. Similar findings were also suggested by Okwuagwu et al. (2008), Okoye et al. (2009) and Noh et al. (2012). The experimental coefficients of variation (CV \%) were low for all the studied traits, suggesting the presence of little influence of the experimental error, i.e $8.4 \%$ for fresh fruit bunch yield, $7.3 \%$ for bunch number, $10.8 \%$ for oil yield, $15.5 \%$ for kernel to bunch, $12.3 \%$ for kernel to fruit, $17.7 \%$ for kernel yield and $14.7 \%$ for height increment. Okwuagwu et al. (2008) stated that, for perennial crops, the reasonable coefficient of variation values should not exceed $30 \%$.

\section{Genetic Parameters and Means of Traits}

The statistical estimate of genetic parameters means and ranges of all the characters are combined in Table 4 . The result revealed that for all the traits, the phenotypic coefficient 
Table 2. Determination of oil palm physical bunch analysis parameters sheet (Mandal and Kochu, 2008)

Recorded data sheet formula

Bunch weight $(\mathrm{kg})$

Code

Stalk weight $(\mathrm{kg})$

A

Spikelet weight in $1 / 4^{\text {th }}$ Bunch $(\mathrm{kg})$

$\mathrm{B}$

Fruit weight in $1 / 4^{\text {th }}$ Bunch $(\mathrm{kg})$

C

No. of fruits in $500 \mathrm{~g}$ fruits

$\mathrm{D}$

Weight of nuts in $500 \mathrm{~g}$ fruits $(\mathrm{g})$

Drying of mesocarp for estimation of moisture content in mesocarp

Weight of container (petriplate) (g)

Weight of shell in $500 \mathrm{~g}$ fruits $(\mathrm{g})$ Drying of kernel for estimation of moisture content in kernel

Initial weight (mesocarp + container) $(\mathrm{g})$

G1

Dry weight of (mesocarp + container) $(\mathrm{g})$

Weight of container $(\mathrm{g})$

$\begin{array}{ll}\text { Initial weight of (container }+ \text { kernel })(\mathrm{g}) & \mathrm{I} 2\end{array}$

Dry weight of (container + kernel) $(g) \quad$ I3

Mesocarp oil estimation

Weight of round bottom flask (g)

Weight of mesocarp (g)

Weight of round bottom flask + oil $(\mathrm{g})$

Average FFB yield/palm/year $(\mathrm{kg})$

$\begin{array}{ll}\text { Code } & \text { Formula } \\ \mathrm{K} & =\mathrm{A}-\mathrm{B} \\ \mathrm{L} & =(\mathrm{K} / \mathrm{N}) \times 100 \\ \mathrm{M} & =(\mathrm{D} / \mathrm{C}) \times 100 \\ \mathrm{~N} & =(\mathrm{L} \times \mathrm{M}) \times 100 \\ \text { Not required } & =500 / \mathrm{E} \\ \mathrm{O} & =[(500-\mathrm{F}) / 500] \times 100 \\ \mathrm{P} & =(\mathrm{O} \times \mathrm{N}) / 100 \\ \mathrm{Q} & {[(\mathrm{G} 2-\mathrm{G} 3) /(\mathrm{G} 2-\mathrm{G} 1)] \times 100} \\ \mathrm{R} & {[(\mathrm{I} 2-\mathrm{I} 3) /(\mathrm{I} 2-\mathrm{I} 1)] \times 100} \\ \mathrm{~S} & {[(\mathrm{~J} 3-\mathrm{J} 1) / \mathrm{J} 2] \times 100} \\ \mathrm{~T} & {[\mathrm{~S} \times(100-\mathrm{Q})] / 100} \\ \mathrm{U} & (\mathrm{T} \times \mathrm{P}) / 100 \\ \text { Not required } & \mathrm{U} \times \mathrm{Y} \\ \text { V } & =[(\mathrm{F}-\mathrm{H}) / 500] \times 100 \\ \text { W } & =(\mathrm{V} \times \mathrm{N}) / 100 \\ \text { Not required } & =\mathrm{W} \times \mathrm{Y} \\ & \end{array}$

of variation ( $\mathrm{PCV} \%$ ) was moderately higher than their corresponding genotypic coefficient of variation (GCV \%). Thus, the result was illustrating the relative consistent effect of the environmental factors on the expression of these traits for the studied oil palm breeding population. This assertion was determined also by the narrow difference between PCV and GCV estimates recorded for all these characters and suggesting their environmental factor tolerance potential for this oil palm population (Table 4). The same appreciation was reported by Okwuagwu et al. (2008), Bozokalfa et al. (2010), Ogunniyan and Olakojo (2015).

\section{Heritability Estimate}

High broad sense heritability estimates were obtained for most of the traits, i.e $78.33 \%$ for fresh fruit bunch yield, 
Table 3. Compiled analyses of variance for fresh fruit bunch yield, number of bunches, oil yield, kernel to bunch, kernel to fruit, kernel yield, and height increment (HT) in the $3^{\text {rd }}$ cycle of selection progeny test Deli $\mathrm{x}$ tenera oil palm breeding population in Cameroon

\begin{tabular}{lcccccccc}
\hline $\begin{array}{l}\text { Sources of } \\
\text { variation }\end{array}$ & $\begin{array}{c}\text { Degree of } \\
\text { freedom }\end{array}$ & \multicolumn{7}{c}{ Mean squares of traits } \\
\hline & & FFB & BN & OY & K/B & K/F & KY & HT \\
\cline { 2 - 9 } Replications & 2 & 111.00 & $3.197^{*}$ & $1.273^{*}$ & 33.519 & 46.67 & 1.728 & $77.182^{* *}$ \\
Progenies & 24 & $403.62^{* * *}$ & $8.717^{* * *}$ & $1.255^{* * *}$ & $206.53^{* * *}$ & $429.38^{* * *}$ & $8.311^{* * *}$ & $39.115^{* *}$ \\
Residuals & 48 & 87.47 & 0.700 & 0.368 & 39.378 & 57.71 & 1.318 & 14.303 \\
C.V (\%) & & 8.40 & 7.400 & 10.800 & 15.500 & 12.30 & 17.700 & 14.700 \\
\hline
\end{tabular}

Significant codes: *** 0.001;** 0.01;*0.05; fresh fruit bunch yield (FFB); number of bunches (BN); oil yield (OY); kernel to bunch $(\mathrm{K} / \mathrm{B})$; kernel to fruit $(\mathrm{K} / \mathrm{F})$; kernel yield $(\mathrm{KY})$; height increment $(\mathrm{HT})$

$91.97 \%$ for bunch number, $86.56 \%$ for kernel to fruit ratio, $80.93 \%$ for kernel to bunch ratio, $70.72 \%$ for oil yield, $84.14 \%$ for kernel yield and $63.43 \%$ for height increment. This result should be associated with the genotype variability observed in the studied breeding population. Similar findings have been reported by Okwuagwu et al. (2008). However, the presence of high broad sense heritability will not eventually signify favourable response to selection because it is related to non-additive gene effects. Therefore, the high estimate of broad sense heritability should be associated to high genetic advance as percent of means of traits for their improvement through selection (Jalata et al., 2011; Jalal and Ahmad, 2012).

Genetic Advance and Expected Genetic Advance as percent of mean

The estimates of expected genetic advance (GA) for fresh fruit bunch was $15.9 \mathrm{~kg}$ per palm per year indicating that whenever we select the best, $10 \%$ high performance crossings as parents, mean FFB of descendants could be improved by $15.9 \mathrm{~kg}$ per palm per year, that is, mean genotypic value of the new population for FFB will be improved from 109.48 to $125.38 \mathrm{~kg}$ per palm per year. In the same way, it will be $13.9,6.3$ ton $\mathrm{ha}^{-1}, 51.8 \%$, $79.3 \%, 8.7$ ton $\mathrm{ha}^{-1}, 21.7 \mathrm{~cm}$ for bunch number, oil yield, kernel to bunch, kernel to fruit, kernel yield and height increment respectively (Table 4). The estimates of expected genetic advance for all the plant traits were slightly high when calculated at $10 \%$ selection intensity, except for palm oil yield performance. However moderate genetic advance as percent of mean was recorded for all traits, inferring that in this studied oil palm breeding population, traits were controlled by additive genes. It revealed the feasibility of the selection for these characters and hence these traits can be improved through their phenotypic performance. The result of genetic advance also showed that selection for palm oil yield performance can be more promising by indirect selection of FFB and BN characters, but mainly for FFB than BN (15.9 kg per palm per year and 2.8 bunches respectively). High estimate of broad sense heritability being recorded and associated with moderate genetic advance as percent of mean for all the traits of these genotypes the characters can be improved through selection

Table 4. Genetic parameters of variation for the 7 studied characters in 23 DxT oil palm progenies of Cameroon

\begin{tabular}{lccrrrrrrrr}
\hline Traits & Mean & Range & GV & PV & $\begin{array}{r}\text { GCV } \\
(\%)\end{array}$ & $\begin{array}{r}\text { PCV } \\
(\%)\end{array}$ & $\begin{array}{r}\text { Hbs } \\
(\%)\end{array}$ & GA & $\begin{array}{r}\text { GA as } \\
\% \text { of } \\
\text { mean }\end{array}$ & $\begin{array}{c}\text { Control } \\
\text { plant }\end{array}$ \\
\hline $\begin{array}{l}\text { Fresh fruit bunch }(\mathrm{kg} \\
\text { per palm per year) }\end{array}$ & 109.48 & $90.33-146.3$ & 105.38 & 134.54 & 9.38 & 10.59 & 78.33 & 15.9 & 14.56 & 129.30 \\
Bunch number & 11.13 & $8.07-13.53$ & 2.67 & 2.91 & 14.68 & 15.31 & 91.97 & 2.8 & 24.72 & 13.53 \\
Oil yield (ton ha $^{-1}$ ) & 5.52 & $4.38-6.35$ & 0.30 & 0.42 & 9.86 & 11.72 & 70.72 & 0.8 & 14.55 & 6.29 \\
Kernel to bunch (\%) $^{2}$ & 40.02 & $27.56-56.14$ & 55.72 & 68.84 & 18.65 & 20.73 & 80.93 & 11.8 & 29.45 & 44.98 \\
Kernel to fruit (\%) & 61.09 & $43.54-85.5$ & 123.89 & 143.13 & 18.22 & 19.58 & 86.56 & 18.2 & 29.75 & 69.85 \\
Kernel yield (ton ha-1) & 6.27 & $4.40-9.66$ & 2.33 & 2.77 & 24.36 & 26.56 & 84.14 & 2.5 & 39.21 & 8.29 \\
Height increment (cm) & 25.69 & $21.41-35.78$ & 8.27 & 13.04 & 11.20 & 14.06 & 63.43 & 4.0 & 15.65 & 25.08 \\
\hline
\end{tabular}

Note: $\mathrm{GV}=$ genotypic variance; $\mathrm{PV}=$ phenotypic variance; $\mathrm{GCV}=$ genotypic coefficients of variation; $\mathrm{PCV}=$ phenotypic coefficients of variation; $\mathrm{GA}=$ genetic advance; $\mathrm{H}_{\mathrm{bs}}=$ broad sense heritability 
based on the phenotypic expression (Akinwale et al., 2011). Okoye et al. (2009) reported high broad sense heritability and high genetic advance as percent of mean for the studied characters.

Oil Palm Population Performance

The results of 10 years of performance for the 23 oil palm crosses DxT for all the studied characters are presented in Table 5. The trial means for bunch number, fresh fruit bunch, kernel to fruit, kernel to bunch, oil yield, kernel yield and height increment were $11.133 ; 109.481 \mathrm{~kg}$ per year; $61.089 \% ; 40.020 \% ; 5.518$ ton $\mathrm{ha}^{-1}$ per year; 6.268 ton $\mathrm{ha}^{-1}$ per year and $25,685 \mathrm{~cm}$ respectively. The information of progeny performance revealed that the palm oil yield was ranged from 4.38 ton $\mathrm{ha}^{-1}$ per year for LM21787 progeny to 6.35 ton $\mathrm{ha}^{-1}$ per year for LM21761 progeny. The recorded palm oil yield mean 5.52 ton ha ${ }^{-1}$ was remarkable high compared to the current Cameroon commercial variety (4.52 ton $\mathrm{ha}^{-1}$; thus $122 \%$ ) reported by Bakoume et al.
(2010). The Duncan's new multiple range test (DMRT) further revealed that 3 progenies and the control genetic material were relatively comparable for high palm oil yield performance in the studied population. These progeny palms yielded more than 6 ton $\mathrm{ha}^{-1}$ per year of CPO and no significant difference was obtained among them. They were also relatively short with annual height increment value found from 21.41 to $27.66 \mathrm{~cm}$ compared to $39.4-53.3 \mathrm{~cm}$ of the current commercial planting materials (Bakoume et al, 2010). However, the selection progress at $10 \%$ of the studied progeny entries allowed only LM21761 and LM21790 to be released as new highest yielding oil palm genetic material progenies in terms to select their self-crossing parents for seed production program with a potential production of 6.26 ton CPO ha-1 per year, that is $99,5 \%$ of the control. The world highest palm oil potential production was reported as 5.52 ton $\mathrm{ha}^{-1}$, and 4.31 ton $\mathrm{ha}^{-1}$ for Indonesia and Malaysia respectively (MPOB, 2016).

Table 5. Mean performance of 23 oil palm introgressed progenies and the control for 7 traits in Cameroon

\begin{tabular}{|c|c|c|c|c|c|c|c|}
\hline Progeny & FFB & $\mathrm{BN}$ & $\mathrm{K} / \mathrm{B}$ & $\mathrm{K} / \mathrm{F}$ & $\mathrm{KY}$ & $\mathrm{OY}$ & HT \\
\hline LM 21761 & $122.3 \mathrm{abc}$ & $12.4 \mathrm{bc}$ & $33.73 \mathrm{efg}$ & 51.64fghi & $5.96 \mathrm{cdef}$ & $6.35 \mathrm{a}$ & $24.08 \mathrm{c}$ \\
\hline LM 21661* & $129.3 \mathrm{a}$ & $13.53 \mathrm{a}$ & 44.98abcd & 69.85 bcde & $8.29 \mathrm{ab}$ & $6.29 a$ & $25.78 \mathrm{c}$ \\
\hline LM 21790 & $118.7 \mathrm{bcde}$ & $13.45 \mathrm{a}$ & $54.07 \mathrm{ab}$ & $80.32 \mathrm{ab}$ & $9.12 \mathrm{a}$ & $6.16 \mathrm{a}$ & $21.41 \mathrm{c}$ \\
\hline LM 22534 & $118.1 \mathrm{bcde}$ & $11.19 \mathrm{cdefg}$ & $33.00 \mathrm{efg}$ & $50.20 \mathrm{ghi}$ & $5.53 \mathrm{cdef}$ & $6.14 \mathrm{a}$ & $27.66 \mathrm{c}$ \\
\hline LM 21925 & $124.2 \mathrm{ab}$ & $13.22 \mathrm{a}$ & $52.81 \mathrm{ab}$ & $78.06 \mathrm{abc}$ & $9.39 \mathrm{a}$ & $6.01 \mathrm{~b}$ & $26.82 c$ \\
\hline LM 22130 & $115.8 \mathrm{bcde}$ & $12.56 \mathrm{bc}$ & 40.94bcdef & $64.21 \mathrm{cdefg}$ & $6.80 \mathrm{bcde}$ & $5.88 \mathrm{~b}$ & $24.20 \mathrm{c}$ \\
\hline LM 22478 & 112.3bcdef & 10.62defgh & 36.48defg & 55.13defghi & $5.87 \mathrm{cdef}$ & $5.83 b$ & $35.12 \mathrm{ab}$ \\
\hline LM 21867 & 118.1bcde & $13.14 \mathrm{a}$ & $27.56 \mathrm{~g}$ & $43.54 \mathrm{i}$ & 4.69def & $5.83 b$ & $24.67 \mathrm{c}$ \\
\hline LM 21728 & $120.4 \mathrm{bcd}$ & $13.46 \mathrm{a}$ & $56.14 \mathrm{a}$ & $85.50 \mathrm{a}$ & $9.66 \mathrm{a}$ & $5.79 b$ & $35.78 \mathrm{a}$ \\
\hline LM 21852 & 113.9bcde & $10.29 \mathrm{efgh}$ & $40.5 \mathrm{bcdef}$ & $61.76 \mathrm{cdefgh}$ & $6.62 \mathrm{bcdef}$ & $5.79 b$ & $26.40 \mathrm{c}$ \\
\hline LM 21709 & 117.1bcde & $12.8 \mathrm{ab}$ & $49.23 \mathrm{abc}$ & 74.42abcd & $8.25 \mathrm{ab}$ & $5.77 \mathrm{~b}$ & $24.82 \mathrm{c}$ \\
\hline LM 22527 & 113.2bcdef & $12.04 \mathrm{bcd}$ & $36.13 \mathrm{defg}$ & 54.33efghi & $5.88 \mathrm{cdef}$ & $5.75 b$ & $26.62 c$ \\
\hline LM 22099 & $107.8 \mathrm{cdef}$ & $10.65 \mathrm{defgh}$ & $35.68 \mathrm{defg}$ & 51.45fghi & $5.45 \mathrm{cdef}$ & $5.63 \mathrm{bc}$ & $22.69 c$ \\
\hline LM 22575 & $108.2 \mathrm{bcdef}$ & $11.56 \mathrm{bcde}$ & 35.94defg & 55.39defghi & $5.54 \mathrm{cdef}$ & $5.49 \mathrm{bcd}$ & $21.80 \mathrm{c}$ \\
\hline LM 22001 & $103.9 \mathrm{def}$ & $11.07 \mathrm{cdefg}$ & $31.31 \mathrm{fg}$ & 49.14hi & 4.64def & $5.46 \mathrm{bcd}$ & $21.65 c$ \\
\hline LM 21874 & $106.2 \mathrm{cdef}$ & $9.75 \mathrm{fgh}$ & $36.52 \mathrm{defg}$ & 55.2defghi & $5.55 \mathrm{cdef}$ & $5.45 \mathrm{bcd}$ & $27.11 \mathrm{c}$ \\
\hline LM 21864 & $108 \mathrm{cdef}$ & $10.36 \mathrm{efgh}$ & $34.66 \mathrm{efg}$ & 53.87efghi & $5.32 \mathrm{cdef}$ & $5.40 \mathrm{bcd}$ & $24.30 \mathrm{c}$ \\
\hline LM 21886 & $106.3 \mathrm{cdef}$ & $11.34 \mathrm{cdef}$ & 43.37abcde & $65.84 \mathrm{bcdef}$ & $6.60 \mathrm{bcdef}$ & $5.20 \mathrm{bcd}$ & $28.04 \mathrm{c}$ \\
\hline LM 21884 & $104.7 \mathrm{def}$ & 10.46defgh & $29.48 \mathrm{fg}$ & $46.44 \mathrm{i}$ & $4.40 \mathrm{f}$ & $5.29 \mathrm{bcd}$ & $28.65 b c$ \\
\hline LM 21839 & $102.2 \mathrm{def}$ & $10.16 \mathrm{efgh}$ & 38.69cdefg & 57.4defghi & $5.61 \mathrm{cdef}$ & $5.15 \mathrm{bcd}$ & $21.46 \mathrm{c}$ \\
\hline LM 21706 & $97.19 \mathrm{ef}$ & $9.58 \mathrm{ghi}$ & 36.01defg & 57.93defghi & $4.99 \mathrm{cdef}$ & $4.87 \mathrm{~cd}$ & $22.77 \mathrm{c}$ \\
\hline LM 21836 & $96.37 \mathrm{ef}$ & $8.58 \mathrm{ij}$ & $49.47 \mathrm{abc}$ & 75.42abcd & $6.81 \mathrm{bcd}$ & $4.81 \mathrm{~cd}$ & $26.09 \mathrm{c}$ \\
\hline LM 21881 & $92.52 \mathrm{f}$ & $9.31 \mathrm{hi}$ & $53.70 \mathrm{ab}$ & $81.89 \mathrm{ab}$ & $6.99 b c$ & $4.48 \mathrm{~d}$ & $25.09 \mathrm{c}$ \\
\hline LM 21787 & $90.33 f$ & $8.07 \mathrm{j}$ & $35.05 \mathrm{efg}$ & 55.96defghi & $4.53 \mathrm{ef}$ & $4.38 \mathrm{~d}$ & $23.52 \mathrm{c}$ \\
\hline
\end{tabular}

Note: *control oil palm material; Numbers followed by the same letter in the same column are not significantly different based on DMRT at $\alpha=0.05 ; \mathrm{FFB}=$ fresh fruit bunch yield; $\mathrm{BN}=$ number of bunch; $\mathrm{OY}=$ oil yield; $\mathrm{K} / \mathrm{B}=$ kernel to bunch; $\mathrm{K} / \mathrm{F}=\mathrm{Kernel}$ to fruit; $\mathrm{KY}=$ kernel yield; $\mathrm{HT}=$ Height increment 


\section{CONCLUSION}

Genetic variability was found among the studied oil palm progeny population, indicating that selection can be done in that oil palm population for the traits of interest. The phenotypic coefficient of variation was relatively higher than the corresponding genotypic coefficient of variation for all the characters. High heritability coupled with moderate expected genetic advance as percent of mean for all the traits were obtained in this study. Selection of the best oil palm crossing parents at $10 \%$ of selection intensity released LM11087T x LM2749D and LM12960T x LM7409D as superior crossing parents yielding 6.26 ton CPO ha ${ }^{-1}$ per year. Thus they can be used for seed production and in the further breeding program.

\section{ACKNOWLEDGMENTS}

The first author greatly acknowledges PT ASTRA AGRO Lestari Tbk Indonesia and Institute of Agricultural Research for Development (IRAD) / Specialized Centre for Oil Palm Research of La Dibamba (CEREPAH) Cameroon for providing financial and technical supports of this research. Bogor Agricultural University (IPB) of Indonesia for the supervision of this study.

\section{REFERENCES}

Akinwale, M.G., G. Gregorio, F. Nwilene, B.O. Akinyele, S.A. Ogunbayo, A.C. Odiyi. 2011. Heritability and correlation coefficient analysis for yield and its components in rice (Oryza sativa L.). African J. Plant Sci. 5:207-212.

Bakoume, C., G. Madi, F.F. Tengoua. 2010. Experimental modification of reciprocal recurrent selection in oil palm breeding in Cameroon. Euphytica 171:235250 .

Bello, O.B., S.A. Ige, M.A. Azeez, M.S. Afolabi, S.Y. Abdulmaliq, J. Mahamood. 2012. Heritability and genetic advance for grain yield and its component characters in maize (Zea mays L.). Internat. J. Plant Res. 2:138-145.

Bozokalfa, K.M., D.E. Ilbi, T.K. Asciogul. 2010. Estimates of genetic variability and association studies in quantitative plant traits of Eruca spp. landraces. Genetika 42:501-512.

Caliman, J.P. 2011. Palmier à huile: le management environnemental des plantations. Le cheminement de PT. Smart. OCL 18:123-131.
Colon-Ramos, U., E.K. Kabagambe, A. Baylin, A. Ascherio, H. Campos, K.E. Peterson. 2007. Socio-economic status and health awareness are associated with choice of cooking oil in Costa Rica. Public Health Nutrition 10:1214-1222.

Hoyle, D., P. Levang. 2012. Oil palm development in Cameroon. An adhoc working paper. WWF/IRD/ CIFOR report.

Jalal, A. Al-Tabbal, H. Al-Fraihat Ahmad. 2012. Genetic variation, heritability, phenotypic and genotypic correlation studies for yield and yield components in promising barley genotypes. J. Agric. Sci. 4:193210.

Jalata, Z., A. Ayana, H. Zeleke. 2011. Variability, heritability and genetic advance for some yield and yield related traits in Ethiopian barley (Hordeum vulgare L.) landraces and crosses. Internat. J. Plant Breed. Genet. 5:44-52.

Jekayinfa, S.O., A.I. Bamgboye. 2008. Energy use analysis of selected palm-kernel oil mills in South Western Nigeria. Energy 33:81-90.

Ladeia, A.M., E. Costa-Matos, R. Barata-Passos, A.C. Guimaraes. 2008. A palm oil rich diet may reduce serum lipids in healthy young individuals. Nutrition 24: 11-15.

Mandal, B.M. Kochu. 2008. Bunch analysis of oil palm. National Research Centre for Oil Palm. Technical Bulletin 8 .

MPOB (Malaysian Palm Oil Board) http://www. palmoilworld.org/PDFs/NKEA-Chapter9-Palm Oil. pdf. August 2016.

Murphy, D. J. 2009. Oil palm: future prospects for yield and quality improvements. Lipid Technol. 21:257-260.

Ngando, E.G.F., M.E.A. Mpondo, E.E.L. Dikotto, P. Koona. 2011. Assessment of the quality of crude palm oil from smallholders in Cameroon. J. Stored Products Postharvest Res. 2:52-58.

Noh, A., M.Y. Rafii, A.M. Din, A. Kushairi, A. Norziha, N. Rajanaidu, M.A. Latif, M.A. Malek. 2014. Variability and performance evaluation of introgressed Nigerian dura x Deli dura oil palm progenies. Genet. Mol. Res. 13:2426-2437. 
Noh, A., M.Y. Rafii, G. Saleh, A. Ku shair, M.A. Latif. 2012. Genetic performance and general combining ability of oil palm Deli dura x AVROS pisifera tested on inland soils. The Scientific World Journal. doi:10.1100/2012/792601.

Ogunniyan, D.J., S.A. Olakojo. 2015. Genetic variation, heritability, genetic advance and agronomic character association of yellow elite inbred lines of maize (Zea mays L.). Nigerian J. Genet. 28:24-28.

Okoye, M.N., C.O. Okwuagwu, M.I. Uguru. 2009. Population improvement for fresh fruit bunch yield and yield components in oil palm (Elaeis guineensis Jacq.). American-Eurasian J. Sci. Res. 4:59-63.

Okwuagwu, C.O., M.N. Okoye, E.C. Okolo, C.D.Ataga, M.I. Uguru. 2008. Genetic variability of fresh fruit bunch yield in Deli/dura $\mathrm{x}$ tenera breeding populations of oil palm (Elaeis guineensis Jacq.) in Nigeria. J. Trop. Agric. 46:52-57.

Singh, R., M.O. Abdullah, E.T.L. Low, M.A.A. Manaf, R. Rosli, R. Nookiah, L.Cheng-Li Ooi, S. Eng Ooi, K.L. Chan, M.A. Halim, N. Azizi, J.Y. Nagappan, B.
Bacher, N. Lakey, S.W. Smith, D. He, M. Hogan, M.A. Budiman, E.K. Lee, R. DeSalle, D. Kudrna, J.L. Goicoechea, R.A. Wing, R.K. Wilson, R.S. Fulton. 2013. Oil palm genome sequence reveals divergence of interfertile species in old and new worlds. Nature 500:335-339.

Sumathi, S., S.P. Chai, A.R. Mohamed. 2008. Utilization of oil palm as a source of renewable energy in Malaysia. Renewable Sustainable Energy Rev. 12:2404-2421.

Sungkono, Trikoesoemaningtyas, D. Wirnas, D. Sopandie. 2009. Pendugaan parameter genetic dan seleksi galur mutan sorgum (Sorghum bicolor (L.) Moench) di tanah masam. J. Agron. Indonesia 37:220-225.

USDA (United States Department of Agriculture) http:// www.indexmundi.com/agriculture/?Commodity =palm-oil November 2016 .

Van Rooyen, J., A.J. Esterhuyse, A.M. Engelbrecht, E.F. du Toit. 2008. Health benefis of a natural carotenoid rich oil: a proposed mechanism of protection against ischaemia/reperfusion injury. Asian Pacific J. Clinical Nutr. 17:316-319. 